\title{
PREGNANCY RATE OF RECIPIENT COWS AFTER TRANSFER OF IN VITRO- PRODUCED NELLORE EMBRYOS ${ }^{1}$
}

\author{
MÔNICA ZUCHELLI JAGUSZESKI ${ }^{2}$, ADALGIZA PINTO NETO ${ }^{2}$, WILLIAM DE OLIVEIRA ${ }^{2 *}$, JONATAS \\ CATTELAM $^{3}$, HELTON APARECIDO GARCIA GREGIANINI ${ }^{4}$
}

\begin{abstract}
The objective of this study was to evaluate the pregnancy rate (PR) of cows of six farms in Bolivia and in the states of Acre and Rondônia in Brazil after the transfer of 4,321 in vitro Nellore embryos produced by a private company, in 2015 to 2016. The effects of the farm location, year of embryo transfer (ET), season of ET, number of previous ET per recipient, and embryo development stage on the PR of the recipient cow (chi square $p<0.05$ ) were evaluated. The PR of the six evaluated farms were similar, with an average of $45.15 \%$. The farm location, year of ET (2015 or 2016), and season of ET (rainy or dry season) did not affect the PR $(p>0.05)$. The PR found after embryo transfer for recipient cows that had already been used once $(45.58 \%)$ or twice $(43.40 \%)$ for this purpose were higher than that of recipient cows used three to eight times $(29.01 \%)(p<0.05)$. ET at expanded or hatched blastocyst stage resulted in higher PR $(47.35 \%)$ when compared to the ET at morula or initial blastocyst $(41.06 \%)$ and at blastocyst stage $(43 \%)(p<0.05)$, which did not differ from each other $(p>0.05)$. Under the conditions of this study, the transfer of in vitro-produced Nellore embryos at advanced development stages (expanded or hatched blastocyst) results in higher PR in cows that had been used once or twice for this purpose.
\end{abstract}

Keywords: Bovine. Embryo transfer. In vitro production. Pregnancy rate.

\section{DESEMPENHO DE RECEPTORAS DE EMBRIÕES NELORE PRODUZIDOS IN VITRO}

RESUMO - A taxa de gestação (TG) foi avaliada após a transferência de 4321 embriões Nelore produzidos in vitro (PIV) pela empresa In Vitro Acre ${ }^{\circledR}$, de 2015 a 2016, em seis propriedades localizadas no Acre, Rondônia e Bolívia. A TG e os efeitos da propriedade, localização, ano, estações, tempo fixo de transferência de embrião técnico, número de transferências anteriores por receptora e estágio do desenvolvimento embrionário foram analisados (Qui-quadrado - p <0,05). A TG foi semelhante nas propriedades 1, 2, 3, 4, 5 e $6(45,85 \%, 42,17 \%$, $46,81 \%, 46,04 \%, 45,74 \%$ e 43,22\%, respectivamente), nas propriedades do Acre, Rondônia e Bolívia (45,16\%, $46,81 \%$ e 43,22\%, respectivamente), em 2015 e 2016 (45,03\% e 45,09\%, respectivamente), nas águas e seca $(44,15 \%$ e $45,72 \%$, respectivamente) e entre os técnicos 1,2 e $3(45,19 \%, 46,32 \%$ e 44,18\%, respectivamente) $(\mathrm{p}>0,05)$. A maior TG após transferência foi observado em receptoras já utilizados uma ou duas vezes quando comparado as utilizadas de três a oito vezes $(45,58 \%, 43,40 \%$ e 29,01\%, respectivamente) $(p<0,05)$. Blastocistos expandidos ou eclodidos levaram a maiores TG $(47,35 \%)$, quando em estádio de mórula ou blastocisto $(41,06 \%)$ e blastocistos $(43 \%)(p<0,05)$, que não diferiram entre si $(p>0,05)$. Concluiu-se que a TG após a TE de embriões Nelore PIV não foi influenciada pelas propriedades, localização, ano, estações do ano e técnico que realizou TE; e foi maior após TE de blastocistos expandidos ou eclodidos para receptoras já utilizadas uma ou duas vezes para esse fim.

Palavras-chave: Bovinos. Transferência de embriões. Produção in vitro. Taxa de gestação.

\footnotetext{
*Corresponding author

${ }^{1}$ Received for publication in 04/29/2019; accepted in 09/13/2019.

Article extracted from course completion work.

${ }^{2}$ Department of Reproduction Animal, Universidade Federal da Fronteira Sul, Realeza, PR, Brazil; monicajaguszeski@gmail.com ORCID: 0000-0001-7554-7025; adalgiza.uffs@gmail.com - ORCID: 0000-0002-2180-2390; williamoliveira.vet@gmail.com - ORCID: 0000-0002-7027-044X.

${ }^{3}$ Department of Production Animal, Universidade Federal da Fronteira Sul, Realeza, PR, Brazil; jonatas.cattelam@uffs.edu.br - ORCID: 0000-0002-4395-2189.

${ }^{4}$ Department of Production Animal, In Vitro Acre, Rio Branco, AC, Brazil; heltonivacre@gmail.com - ORCID: 0000-0002-6360-7833.
}

Rev. Caatinga, Mossoró, v. 32, n. 4, p. 1087 - 1091, out. - dez., 2019 


\section{INTRODUCTION}

In vitro fertilization has become a viable alternative for embryo production of cattle, especially of zebu breeds (VIEIRA, 2012). It has been used in Brazil not only in scientific research, but also commercially, through transvaginal ultrasound-guided follicle aspiration (RUBIM et al., 2009). In vitro embryo production (IVEP) involves the collection, maturation, fertilization, and cultivation steps, and the efficiency of the in vitro maturation and fertilization steps does not differ from that found the in vivo production (MELLO et al., 2017).

IVEP allows the exploitation of the genetic potential of cows; it has been used commercially in Brazil and worldwide (MELLO et al., 2017), allowing a rapid increase of the number of genetically superior animals, decrease in the generation interval, and increase in the selection intensity (PALHANO, 2008). However, embryo transfer (ET) requires acquisition, maintenance, and use of a significant number of recipient cows, which represents a large proportion of the costs and determines the number of products generated in IVEP programs (BELTRAME et al., 2007).

The pregnancy rates after fixed-time artificial insemination (FTAI), natural breeding, and ET after IVEP, presented differences of $62 \%$ (VIANA et al., 2015), 74\% (OLIVEIRA JÚNIOR et al., 2008), and 37 to $39 \%$ (ANDRADE et al., 2012), respectively. However, IVEP allows the obtaining of viable embryos from healthy cows of high genetic value, cows with reproductive problems or unable to produce offspring by conventional techniques, cows at pre-pubertal age (six months), and pregnant cows until the third month of gestation or at the postpartum period (MELLO et al., 2017).

The embryonic development stage, embryodonor-recipient synchrony, and embryo and corpus luteum quality are important aspects to be considered in ET programs (in vivo and in vitro), since they directly affect the pregnancy rate (PEIXOTO et al., 2007; LEAL et al., 2009; ANDRADE et al., 2012; SOUZA; ABADE, 2019). In this context, the objective of the present study was to evaluate the pregnancy rate of recipient cows after transfer of Nellore in vitro-produced embryos.

\section{MATERIAL AND METHODS}

Retrospective data were collected from 4,321 Nellore embryos produced in vitro by a single laboratory technician from a private company (In Vitro Acre ${ }^{\circledR}$ ) located in Rio Branco, Acre, Brazil$9^{\circ} 58^{\prime} 29^{\prime \prime S}, 67^{\circ} 48^{\prime} 36^{\prime \prime} \mathrm{W}$, altitude of 153 meters, and tropical climate. Pubescent, healthy donor cows of the Nellore breed were subjected to a commercial
IVEP technique developed by this private company.

Viable in vitro-produced embryos (IVPE) of Nellore breed were subjected to fixed-time embryo transfer (FTET), by non-surgical method, using hormone-protocol synchronized recipient cows in six farms, which are located in the states of Acre (4 farms) and Rondônia (1 farm) in Brazil, and in Bolivia (1 farm), in the years 2015 and 2016, during the rainy (October to March) and dry (April to September) seasons.

The synchronization of the recipients was achieved by using the commercial fixed-time hormonal protocol as follows:

Day zero: insertion of progesteroneimpregnated siliconized intravaginal implant (Cronipres $^{\circledR}$, Biogénesis Bagó); intramuscular (IM) administration of $2 \mathrm{mg}$ of estradiol benzoate (Bio Estrogen $^{\circledR}$, Biogenesis Bagó), and administration of two IM vaccines $\left(\right.$ Bioabortos ${ }^{\circledR}$, and Bioleptogen ${ }^{\circledR}$, Biogenesis Bagó) against infectious bovine rhinotracheitis (IBR), bovine viral diarrhea (BVD), campylobacteriosis, leptospirosis, and histophylosis. Day 8: progesterone implant withdrawal; IM administration of 300 IU of equine chorionic gonadotrophin (eCG) $\left(\right.$ Ecegon $^{\circledR}$, Biogenesis Bagó), IM administration of $1 \mathrm{mg}$ of Estradiol Cypionate (Croni Cip ${ }^{\circledR}$, Biogenesis Bagó) and $0.15 \mathrm{mg}$ of DCloprostenol (Croniben ${ }^{\circledR}$, Biogenesis Bagó). Day 17: Transfer of Embryos to Recipients - FTET. Day 30: Pregnancy diagnosis and IM additional administration of vaccines as described in Day 0 .

The embryos were transferred to crossbred recipient cows previously used once, twice, or three to eight times for this purpose. The embryo transfer (ET) was performed by a skilled technician, considering the different embryonic development stages - morula or initial blastocyst, blastocyst, and expanded or hatched blastocyst (IETS, 1998).

Pregnancy was diagnosed by examination through ultrasound (Midray 2200) at 20 days after ET, which was reconfirmed at 55 days by the same method. Donor and recipient cows were grazed, supplemented with protein salt, and had access to water ad libitum.

Pregnancy data were collected, tabulated in spreadsheets, and the pregnancy rate was calculated considering the effects of the farm location, year of ET, season of ET, number of previous ET per recipient, and embryonic development stage. The mean percentages were compared using the frequency dispersion test (chi-square); the analyses were performed in the SAS 9.2 program, considering significance level of $p<0.05$.

\section{RESULTS AND DISCUSSION}

The pregnancy rate of recipient cows after the transfer of in vitro-produced embryos (IVPE) of Nellore breed by fixed-time embryo transfer (FTET) 
was $45.15 \%(1951 / 4321)$. This pregnancy rate is higher than those found by Andrade et al. (2012) for 1,506 Senepol $(37.6 \% ; 265 / 705)$ and Nellore $(39.1 \% ; 314 / 801)$ cows with IVPE.

IVPE from oocytes of ovaries of Nellore cows, with and without corpus luteum, presented pregnancy rates of 30.81 and $35.20 \%$, respectively (BARBOSA; TONIOLLO; GUIMARÃES, 2013). Even without considering the presence of corpus luteum at the time of ovum pick up (OPU) from Nellore donors, in the present study, the cows presented higher pregnancy rates than those.

Scanavez, Campos and Santos (2013) evaluated the effect of bovine somatotropin and flunixin meglumine and found pregnancy rates of $62.9 \%(87 / 139)$ for recipient cows after ET of $1 / 2$ Holstein $1 / 2$ Gir IVPE, and 57\% (549/961) after ET of $3 / 4$ Dutch $1 / 4$ Gir IVPE. The authors reported that embryos from European breeds provide higher pregnancy rates after ET than those from Zebu breeds. This difference may explain the lower pregnancy rate found in the present study for Nellore embryos (45.15\%; 1,951/4,321).

Pupulim et al. (2010) evaluated 6,415 FTET from IVPE of Nellore breed and Nellore-Angus crossbreed and found pregnancy rates $44.7 \%$ $(1907 / 4263)$ and $37.7 \%(812 / 2152)$ at 30 days after transfer, respectively; and $39.2 \%(1674 / 4263)$ and $32.1 \%$ (692/2152), respectively, at 60 days after transfer. In the present study, pregnancy diagnoses were made between 20 and 55 days after the beginning of the protocol, depending on the management of the participating farms.

The pregnancy rate of the evaluated farms was similar $(p>0.05)$, with average pregnancy rate of $45.15 \% \quad(1951 / 4321)$. Similar pregnancy rate $(p>0.05)$ was also found when considering the location of the farms-Acre (45.16\% 1339/2965), Rondônia (43.22\%; 274/634), and Bolivia (46.81\%; $338 / 722$ ). These results may be associated with the similar food management and management conditions of the farms.

According to Gonçalves, Figueiredo and Freitas (2002), the distance between the IVEP laboratory and the farms where the oocytes are collected and where the embryos were transferred is a limiting factor that can affect the pregnancy rate after the ET of the IVPE. The quality of IVPEs may decrease, making them vulnerable to thermal and oxidative stress because of the long distances for transport, affecting the pregnancy rate after the ET (PUPULIM et al., 2010). However, the pregnancy rate of the cows after the ET of Nellore IVPE was similar, regardless of the distance from the laboratory to the farms approximately $72 \mathrm{~km}$ (Acre), $262 \mathrm{~km}$ (Bolivia), and 364 km (Rondônia).

The pregnancy rate of recipient cows after transfer of Nellore IVPE in $2015 \quad(45.03 \%$; $1038 / 2305)$ and $2016(45.29 \%$; 913/2016) was similar $(p>0.05)$. Moreover, no difference $(p>0.05)$ was found between the pregnancy rates after transfer of IVPE in the rainy $(44.15 \% ; 691 / 1565)$ and dry $(45.72 \% ; 1260 / 2756)$ seasons. Similarities in the management and grazing conditions of the animals among the studied farms, even considering different years and seasons of IVPE transfer, may explain this result.

Colombo, Zaniboni and Cavalieri (2014) evaluated the pregnancy rate of 762 IVPE recipients in a farm in the state of Paraná, Brazil, from December 2010 to July 2011, and found pregnancy rates of $30.16 \%$ in the rainy season (August-April) and $31.64 \%$ in the dry season (May to July). These results are lower than those found in the present study-despite no differences in pregnancy rates were found between the evaluated years and seasons.

Machado (2010) found similar results in the state of São Paulo, Brazil, with recipients of crossbred embryos with no differences in pregnancy rates after ET in the dry and rainy seasons - $32.4 \%$ $(12 / 37)$ to $44.4 \%(16 / 36)$, and $49.1(28 / 57)$ to $56.6 \%$ (30/53), respectively.

Different pregnancy rates $(p<0.05)$ were found for the number of previous ET per recipient, with higher pregnancy rates when transferring Nellore IVPE to recipients that had been used once $(45.58 \% ; 1468 / 3221)$ or twice $(43.40 \% ; 322 / 742)$ for this purpose when compared to recipients previously used three to eight times $(29.01 \% ; 161 / 555)$.

Silva et al. (2017) evaluated crossbred heifers used as embryo recipients for the first time and found a similar pregnancy rate $(p>0.05)$ at 35 days when using flunixin meglumine $(55 \% ; 24 / 40)$, somatotropin $(60 \% ; 22 / 40)$, and a control group $(53.33 \% ; 16 / 30)$

The pregnancy rate after transfer of Nellore IVPE to recipients that had one or two previous ET was similar in the present study. Differences from results found in other studies may due to the low number of ET used.

Colombo, Zaniboni and Cavalieri (2014) evaluated the pregnancy rate of cows after transfer of Nellore IVPE in 2010 and 2011 and found that cows used as recipients one $(34.3 \%)$, two $(33.07 \%)$, or three $(34.08 \%)$ times present similar pregnancy rates; and recipients used four times present lower pregnancy rates $(16.42 \%)$.

Attention on the health, nutrition, and wellbeing of the recipient cows is essential for them to respond to the hormonal treatments required for FTET to result in one deliver per year and in heavy, healthy weaned calves (HONORATO et al., 2013). The management of the recipient cows used in the present study may explain the pregnancy rates found after ET of Nellore IVPE, which were higher than those found in similar studies (ANDRADE et al., 2012; LEAL et al., 2009; SCANAVEZ; CAMPOS; SANTOS, 2013; PUPULIM et al., 2010; MOSCHINI; BARREIROS, 2016; SILVA et al., 2017). 
The embryo development stage affected the pregnancy rate of cows after transfer of Nellore IVPE. The pregnancy rate found after ET of embryos at expanded or hatched blastocyst stage $(47.35 \%$; $1213 / 2562)$ was higher $(p<0.05)$ than those found at morula or initial blastocyst stage $(41.06 \% ; 388 / 557)$ and at blastocyst stage $(43 \% ; 350 / 814)$ — which were statistically similar $(p>0.05)$.

Veloso Neto et al. (2014) found similar results after ET of Nellore IVPE, with higher pregnancy rate for developed embryos (blastocyst and expanded blastocyst) $(57.14 \% ; 56 / 98)$ than that for young embryos (morula and initial blastocyst) $(25 \% ; 9 / 36)$. Considering that the embryos are transferred, on average, seven days after fertilization, it is expected that most embryos will be at the blastocyte stage (seven days), since they reach the morula-initial blastocyst stage at 4-5 days and the expanded or hatched blastocyst stage after eight days (IETS, 1998).

Fonseca et al. (2001) evaluated 135 IVPE of Standard Nellore, Hornless Nellore, and Guzera breeds and found predominantly embryos at the expanded blastocyst stage $(42.2 \% ; 57 / 135)$ when compared to embryos at the morula stage (3.5\%; $5 / 135)$. Superior results were found in the present study, with 2,562 (59.19\%) of the 4,321 Nellore IVPE were at the expanded or hatched blastocyst stage, and $945(21.87 \%)$ were at the morula or initial blastocyst stage

\section{CONCLUSION}

The transfer of in vitro-produced Nellore embryos at advanced stages of development (expanded or hatched blastocysts) results in a higher pregnancy rate, especially when transferred to cows previously used once or twice for this purpose.

\section{REFERENCES}

ANDRADE, G. A. et al. Fatores que afetam a taxa de gestação de receptoras de embriões bovinos produzidos in vitro. Revista Brasileira de Reprodução Animal, v. 36, n. 1, p. 66-69, 2012.

BARBOSA, C. P.; TONIOLLO, G. H.; GUIMARÃES, E. C. Produção in vitro de embriões de bovinos da raça nelore oriundos de ovócitos de ovários com e sem corpo lúteo. Ciência Animal Brasileira, v. 14, n. 1, p. 81-90, 2013.

BELTRAME, R. T. et al. Economic optimization of the number of recipientes in bovine embryo transfer programs. Scientia Agricola, v. 64, n. 3, p. 221-226, 2007.
COLOMBO, A. H. B; ZANIBONI, L; CAVALIERI, F. L. B. Efeito do período e do número de animais na taxa de gestação de receptoras submetidas à transferência de embriões provenientes da produção in vitro. Revista em Agronegócios e Meio Ambiente, v. 7, n. 1, p. 11-19, 2014

FONSECA, J. F. et al. Estádios de desenvolvimento embrionário de vacas zebuínas superovuladas. Arquivo Brasileiro de Medicina Veterinária e Zootecnica, v. 53, n. 6, p. 671-676, 2001.

GONÇALVES, P. B. D.; FIGUEIREDO, J. R.; FREITAS, V. J. F. Biotécnicas Aplicadas à Reprodução Animal. 1. ed. São Paulo, SP: Livraria Varela; 2002. 340 p.

HONORATO, M. T. et al. Importância da escolha de receptoras em um programa de transferência de embriões em bovinos. PUBVET, v. 17, n. 19, p. 128,2013

LEAL, L. S. et al. Avaliação do corpo lúteo, contratilidade uterina e concentrações plasmáticas de progesterona e estradiol em receptoras de embriões bovinos. Ciência Animal Brasileira, v. 10, n. 1, p. 174-183, 2009.

MACHADO, R. Estratégias para reduzir a mortalidade embrionária em bovinos. II. Protocolo para reduzir a mortalidade embrionária em vacas de leite e em receptoras de embrião. 1. ed. São Carlos, SP: Embrapa Pecuária Sudeste, 2010. 21 p.

MELLO, R. R. C. et al. Produção in vitro (PIV) de embriões em bovinos. Revista Brasileira de Reprodução Animal, v. 40, n. 2, p. 58-64, 2017.

MOSCHINI, G. A. L.; BARREIROS, T. R. R. Comparação das taxas de gestação e perdas gestacionais de embriões produzidos in vitro da raça Nellore ou cruzas Angus $x$ Nellore. In: VI JORNADA DE INICIAÇÃO CIENTÍFICA DA UNEP, 6., 2016. Cornélio Procópio. Anais.. Cornélio Procópio, 2016.

OLIVEIRA JÚNIOR, D. R. et al. Relação entre circunferência escrotal de touros Nellore e taxa de gestação de vacas em monta natural. Boletim de Indústria Animal, v. 73, n. 4, p. 319-328, 2008

PALHANO, H. B. Reprodução em bovinos: fisiopatologia, terapêutica, manejo e biotecnologia. 2 ed., Rio de Janeiro, RJ: L. F. Livros; 2008. 249 p.

PEIXOTO, M. G. C. D. et al. Logistic regression analysis of pregnancy rate following transfer of Bos indicus embryos into Bos indicus and Bos Taurus 
heifers. Theriogenology, v. 67, n. 2, p. 287- 292, 2007.

PUPUliM, A. G. R. et al. Meio de transporte embrionário e temperatura de transporte em blastocistos bovinos produzidos in vitro. In: XXIV REUNIÃO ANUAL DA SOCIEDADE BRASILEIRA DE TECNOLOGIA E EMBRIÕES, 24., Porto de Galinhas. Anais... Porto de Galinhas, 2010. p. 384.

RUBIM, M. I. B. et al. Produção in vitro de embriões e Clonagem: um caminho conhecido? Revista Brasileira de Reprodução Animal, v. 6, n. 6, p. 77-85, 2009.

SCANAVEZ, A. L.; CAMPOS, C. C.; SANTOS, R. M. Taxa de gestação e de perda de gestação em receptoras de embriões bovinos produzidos in vitro. Arquivo Brasileiro de Medicina Veterinária e Zootecnia, v. 65, n. 3, p. 722-728, 2013.

SILVA, J. C. F. et al. Efeito do flunixin meglumine e da somatotropina recombinante bovina sobre a taxa de gestação de receptoras bovinas de embriões fecundados in vitro. Medicina Veterinária, v. $8, \mathrm{n}$. 3, p. 11-16, 2017.

\section{SOCIEDADE INTERNACIONAL DE TRANSFERÊNCIA DE EMBRIÕES - IETS. Manual da Sociedade Internacional de Transferência de Embriões. 3. ed. Illinois: IETS, 1998. $180 \mathrm{p}$.}

SOUZA, N. S.; ABADE, C. C. Produção in vitro de embriões bovinos: etapas de produção e histórico no Brasil. Ciência Veterinária UniFil., v. 1, n. 3, p. 95 $108,2019$.

VELOSO NETO, H. F. et al. Parâmetros que afetam a taxa de prenhez de receptoras bovinas de embriões produzidos in vitro. Medicina Veterinária, v. $8, \mathrm{n}$. 3, p. 31-35, 2014.

VIANA, W. et al. Taxa de prenhez de vacas zebuínas com uso da inseminação artificial em tempo fixo (IATF) em fazendas do norte de Minas Gerais. Revista Científica Eletrônica de Medicina Veterinária, v. 24, n. 24, p. 1-8, 2015.

VIEIRA, R. J. Biotécnicas aplicadas à reprodução bovina: generalidades. Ciência Animal, v. 22, n. 24, p. 55-65, 2012. 